\title{
Features of Socio-Psychological Adaptation of Personality in the Situation of Ethnic Migration
}

\section{Особливості соціально-психологічної адаптації особистості в ситуації етнічної міграції}

Iryna Vashchenko

Dr. in Psychology,

Professor

\author{
Ірина Ващенко \\ доктор психологічних наук, \\ професор
}

E-mail: jarinavv62@gmail.com orcid.org/0000-0003-4424-5790

Researcher ID: C-4934-2019

Taras Shevchenko National

University of Kyiv,

Kyiv, Ukraine

64/13, Volodymyrska street,

Kyiv, 01601

Yuliia Rittel

Graduate Student of the Institute of Postgraduate Education
Київський національний університет ілені тараса Шевченка, м. Київ, Украӥна

вул. Володимирська, 64/13, м. Київ, 01601

Юлія Ріттель магістрант Інституту післядипломної освіти

E-mail: fonrittel@ukr.net orcid.org/0000-0002--8963-5365

Researcher ID: H-2426-2019

Taras Shevchenko National University of Kyiv,

Kyiv, Ukraine

64/13, Volodymyrska street, Kyiv, 01601
Київський національний університет ілені тараса Шевченка, л. Київ, Україна вул. Володимирська, 64/13, м. Київ, 01601 
Original manuscript received March 10, 2019

Revised manuscript accepted March 25, 2019

The author's contribution: I. Vashchenko $-50 \%$, Y. Rittel $-50 \%$. Авторський внесок: І. Ващенко - 50\%, Ю. Ріттель - 50\% .

\section{ABSTRACT}

The article is devoted to the problem of the features of socio-psychological adaptation of personality in the situation of ethnic migration. The emphasis is placed on the categories of voluntary ethnic migrants who are in the process of social and psychological adaptation to the conditions of the Ukrainian metropolis. The external and internal factors of social and psychological adaptation, influence of age of ethnic migrants from Kazakhstan on the success of the adaptation process are analysed. The difficulties encountered during social and psychological adaptation to the new society are empirically determined, and the parameters that influence the success of the interaction of different cultures in society. According to the results of the correlation analysis of the obtained data, it was found that voluntary ethnic migrants from Kazakhstan aged 18 to 35 years deciding to live, study and work in Ukraine consciously and independently, have acceptable and even high potential level of selfrealization. It is proved that their ethnic identity is absolutely unrelated to the self-actualization tendencies of the person and its adaptability. However, ethnic identity significantly affects the socio-psychological adaptation of ethnic migrants, and sometimes even determines its success. The version of the program of comprehensive support and psychological support of ethnic migrants in the process of their social and psychological adaptation is proposed.

Key words: voluntary ethnic migration, adaptation of personality, sociopsychological adaptation, expressiveness of ethnic belonging, self-actualization, depression, Ukrainian metropolis, psychological support, ethnic identity.

\section{Introduction}

In modern society, with all its peculiarities, processes of transformation, crisis phenomena, changes in priorities, moral and cultural norms, realization of the personality of one's own potential becomes often difficult and sometimes impossible at all. It is not easy to overcome difficulties and to demonstrate self-actualization, especially as an ethnic mi- 
grant who, often without adapting to a new society, is already forced to demonstrate efficiency, productivity and success as the modern living conditions require. Socio-psychological non-adaptation in society can lead to worrying states of migrants and increase the level of depression, which prevents setting up necessary contacts, reduction of social distance, the process of integration, etc. Consequently, ethnic migrants in such a scenario fall into a metaphorical closed circle, from which one rarely can find a way out alone.

Appeal to the problem of studying the socio-psychological adaptation of ethnic migrants is very relevant and represents an important branch of scientific knowledge, presented by numerous works of such authors as: F. Berezin (Berezin, 1988), Dzh. Berri (Berri, 2007), V. Hrytsenko (Hrytsenko, 2005), A. Nalchadzhian (Nalchadzhian, 1988), O. Ovsianyk (Ovsianyk, 2012), A. Smotrytskyi (Smotrytskyi, 2015), as well as works on the study of adaptation in the conditions of social transformations by K. Abulkhanova (Abulkhanova, 1981), L. Antsyferova (Antsyferova, 1994), O. Blynova (Blynova, 2011), L. Naidionova (Naidionova, 2012), N. Panina (Panina, 2005), T. Titarenko (Titarenko, 2007).

In general, socio-psychological adaptation is defined as the continuous process of adapting a person to a cultural, political, economical, elemental everyday social life, in which person lives and perform its activity (Akopov, 2015) as the actual result of the above-mentioned process (Barysheva, 2007).

The definition of psychological adaptation by F. Berezin, which fully reflects the process of social and psychological adaptation of the individual is interesting and traditionally often quoted in Ukrainian scientific circle (Berezin, 1988). According to the scientist, its essence is the process of establishing the optimal correspondence of the person and the environment, which is reflected in the implementation of his / her inherent activity, which allows the individual to meet the actual needs and realize the significant goals associated with them. Similar considerations are found in the works of O. Bly- 
nova, who notes that the maintenance of mental and physical health, while simultaneously ensuring the compliance of human mental activity and its behavior with the requirements of the social environment, is a prerequisite (Blynova, 2011).

The question of the socio-psychological adaptation of an individual acquires particular relevance in the context of the life of ethnic migrants, who often encounter the reality of a new and unfamiliar environment, are forced to overcome the search for adaptive reactions and actions.

O. Blynova describes such mobilization reactions of the person as rational explanations justifying contradictions, conscious filtering of information coming from the environment and the actual change of basic identification of personality (Blynova, 2011).

The person who is in the process of socio-psychological adaptation to the new society with its unique features, often overcomes two opposite trends (on the principle of shuttle movement), which are manifested, firstly, in the pursuit of conservation and self-isolation, supported by the creation of separate, isolated diasporas, and secondly, the desire for assimilation, which sometimes leads to the loss of ethnic identity with complete dissolution in the new society.

In the context of socio-psychological adaptation of ethnic migrants the researchers usually deal with various complex pathological mental states of individuals that arise from the experience of stress and overcoming the crisis challenges that lead to mental stress, maladaptation, distress, depression, loss of meaning in life and decrease self-actualizing personality trends.

Note that in the research tradition to distinguish between the processes of acceptance, in which a group of ethnic migrants absorb another culture, response - when fully rejects new culture, opposes it, and adaptation per se, which actually involves a process of mutual adaptation, exchange and coordination of two different cultures in a unique pattern (Blynova, 2011; Hrytsenko, 2005; Dovhaleva, 2010; Kyryllova, 2013). 
The study of the peculiarities of social and psychological adaptation of a person usually takes place, taking into account the significant aspects of various categories of citizens in general and migrants in particular. For example, a tangible difference will be found in groups of refugees, forced migrants (which is currently briefing for Ukraine), labor migrants and voluntary migrants. Focusing on voluntary migrants themselves, one must take into account that for them the attraction factors are stronger than the factors of squeezing out. It is logical that the main feature of this category of migrants is the orientation towards the higher needs of the individual, in contrast to those who move into the new conditions forced to survive or save life. And, in this case, it is expedient to talk about self-actualization trends and high adaptation resources that will promote integration in the new socio-cultural space. It is worth taking into account the specificity of the group of voluntary migrants in the Ukrainian metropolis (a sample of our study), the features of which can hardly be extrapolated to all ethnic migrants in Ukraine. Therefore, the very aspect of the peculiarities of the socio-psychological adaptation of voluntary ethnic migrants in the metropolis with its specific conditions of life is acquired.

It should be noted that the study of the specifics of sociopsychological adaptation of migrants in a mega-city is the subject of many studies of recent years. The social and cultural potential of the metropolis was studied by sociologists, social psychologists, social philosophers, cultural scientists, who noted the diversity of lifestyles, cultural forms, value orientations of their socio-cultural environment, envisaging the possibility of individual choice of the recipient of the most successful standard of life for him (Smotrytskyi, 2015).

An interesting trend of modern psychological research is the perception of the traditional approach to the consideration of the adaptation of migrants, with its focus on the ethnocultural aspect of this process as an outdated stereotype. It is noted that in modern domestic scientific literature the sub- 
cultures were stopped considering as a marginal formation, countercultures, which opposed the prevailing principles of culture (Smotrytsky, 2015). It is therefore recommended to take into account the fact that voluntary migrants in the process of adaptation can find a way out of the identity crisis in the formation of a positive social identity of the metropolitan type. It is noted that identification with the metropolis, and not with the country as a whole, contributes to the successful social and psychological adaptation of ethnic migrants $\left(\mathrm{Ov}^{-}\right.$ sianyk, 2012). However, we argue that in the context of sociopsychological adaptation of ethnic migrants in Ukraine one has to take into account the specifically complicated situation in the state in recent years, which a priori affected the process of integrating recipients into society through its basic polarization and social instability.

In general, they note that ethnic migrants face adaptation difficulties in the new society, highlighting the parameters that influence the success of the interaction of different cultures in a society: a territory that can be perceived as common to only one group; duration of interaction (constant, long, shortterm); purpose of interaction (joint activity, residence, study, leisure, etc.); feature of involvement in society; frequency and depth of social contacts; relative equality of status, rights, freedoms, etc.; quantitative ratio; obvious distinctive features (language, appearance, religion, etc.) (Blynova, 2011).

Considering the main barriers of social and psychological adaptation of ethnic migrants, we in the context of this work are primarily interested in individual factors, which include socio-demographic characteristics, personal characteristics and life experience of migrants. So, let's recall only briefly about group factors, which usually distinguish between similarities and differences between cultures of recipients and donors, especially cultures that include migrants and indigenous peoples.

Analyzing the external factors of social and psychological adaptation of the individual, we firstly draw attention to the 
environment, its political, economic, cultural and other conditions that the migrant tries to become accustomed to. The most pressing issues of the external barriers to the adaptation of ethnic migrants in Ukraine have been just over the last five years in connection with the military conflict in the East of Ukraine, which completely destabilized the social situation in the state. Since the process of adaptation has a pronounced social character and is revealed in adaptation, interaction, ascent, use, etc., it is easy to simulate the situation in which volunteers migrated among the flows of forced migrants and the permanent population of our megacity.

The forms that a volunteer migrant finds for his adaptation depend on the reasons for his resettlement, the actual circumstances and conditions of life. One of the important variables is the installation of a volunteer migrant for integration in a new environment, since he deliberately decided to change his place of residence and life. However, this does not exclude either housing or household problems, nor employment problems, nor problems of adaptation to a new culture, language, rules, etc.

Among the significant difficulties of the adaptation of ethnic migrants, mention is also made of the relationship with local residents, which is influenced by the role and status structure (hosts and guests, insiders and aliens), as well as the degree of inclusion of migrants into society (active subjects or passive observers), the presence of social niche for migrants.

Mutual misunderstanding, distrust, prejudice, and misconceptions are among the leading factors that influence the complexity of socio-cultural adaptation on both sides, since not only ethnic migrants adapt to the new conditions of the social environment, but also local residents are forced to adapt to an increase in the number of culturally unusual for them persons and common accommodation with them. It is at this point that the need to understand the psychological problems encountered by an ethnic migrant in the process of social and psychological adaptation to a new society is actualized. 
Traditionally, there are two aspects of studying such problems: firstly, social isolation is a lack of contacts with the surrounding environment, which negatively affects the mental state of man and the mechanisms of his social adaptation, and in the future can lead to loneliness, and subsequently to depression; and secondly, the differences between expectations and the real state of the situation, which leads to frustration and, as a consequence, the psychological tension of the individual.

On this basis, it can be said that ethnic migrants inevitably face the dilemma of accepting or non-acceptance of them by the social environment in which they decided to live themselves, but at the same time they meet with a high degree of frustration with their basic needs. Of course, the degree and depth of experience of the personality of her own social deprivation and isolation depends on the social and cultural peculiarities of the host society, the migration policy of Ukraine, the socio-economic and political climate, and so on. However, it is obvious that in the same environment, different migrants live in different ways in social and psychological adaptation, so one must also take into account the internal factors of the difficulties that arise in this process.

Internal factors of social and psychological adaptation of ethnic migrants become subject of psychological research unjustifiably less often than the external side of it. However, it is the reaction of adaptation, the personal characteristics of ethnic migrants is a guarantee of a state of satisfaction with the fullness of life.

The success of the process of socio-psychological adaptation is extremely influenced by the age of the migrant. It is well known that children are adapted much more easily to any environmental conditions (which, by the way, is not enough for them to change, because the most important environment is rather family) even in comparison with school-age children who are forced to adapt simultaneously to the difficult environment of younger children and older teens. However, 
the hardest time seems to be for elderly people who change their place of residence extremely rarely, choosing old age and death in their homes, because they do not feel internal resources for adapting and mastering «alien» rules and norms, language and culture, etc.

The results of modern research are interesting, according to which women from traditional cultures adapt a new social environment more difficult than men, at first glance, due to lack of education and professional competences and experience. However, a more in-depth analysis shows that their difficulty is observed precisely because of the greater need for interaction with others, the more acute desire to be accepted, and hence the heavier experiences of social isolation and frustration.

Among the important factors of socio-psychological adaptation there is the cognitive simplicity of the personality that prevents the world from seeing in its various manifestations, instead it causes the black and white perception of the surrounding environment, which in turn increases the social distance between the migrant and the locals and promotes its isolation. Cognitively complex personalities are easier to establish a short distance with locals, even with significant differences in culture, everyday life, leisure, etc.

Studies of modern psychologists show that authoritarian, rigid and intolerant individuals are much more difficult to adapt in the new conditions of life, they are more difficult to understand the new culture, customs, and the peculiarities of the country in which they decided to live.

A significant factor in social and psychological adaptation is also recognized by the person's life experience, which also includes motivation for moving. Indeed, as we have already mentioned above, voluntary ethnic migrants are strikingly different from those who left their homes forcedly, saving their own lives, or escaping extreme poverty.

An important condition for successful adaptation is also recognition of the knowledge of the language, traditions, pe- 
culiarities of the society in which the ethnic migrant plans to live, as well as familiarity with the locals and the prior establishment of friendly contacts with them. After all, the restriction of social interaction is the first step to increasing the sense of nullity, alienation, inappropriateness, lack of equality, etc.

However, psychological research is currently aimed primarily at researching the problems of social and psychological adaptation of forced migrants, while the issue of integration of ethnic migrants arriving in our country during the period of the beginning of hostilities in the East of the country remains unexplored, although highly relevant. Given this, the problem of studying the peculiarities of socio-psychological adaptation of ethnic migrants in Ukraine, which requires a rethinking at the level of individual knowledge and scientific substantiation of ways to increase the socio-psychological adaptation of ethnic migrants in Ukraine, becomes a matter of particular importance.

The aim of the study is to find out the features of socio-psychological adaptation of ethnic migrants in Ukrainian society.

\section{Tasks of the research:}

to carry out an analysis of modern scientific research into the problem of social and psychological adaptation; to identify psychological peculiarities of ethnic migrants in Ukraine and, in particular, their self-actualization tendencies, to determine the degree of socio-psychological adaptation of migrants from Kazakhstan in Ukrainian society and their depressive tendencies; ways of preserving the ethnic identity of migrants from Kazakhstan in the Ukrainian society; to formulate recommendations for increasing the socio-psychological adaptation of ethnic migrants in Ukraine.

\section{Methods and technologies of research}

According to the purpose of empirical research, we have selected a methodical toolkit: K. Rogers and R. Diamond's 
Method of diagnostics of socio-psychological adaptation of personality; J. S. Phinney's Methodology for studying the expressiveness of ethnicity, E. Shostrum's self-actualization test; T. Beck's Depression Inventory; Questionnaire for additional socio-demographic information of the subjects.

The study was attended by 108 ethnic migrants aged between 18 and 35 who live in Ukraine for no more than 5 years and are currently busy with the issues of adaptation, integration and self-realization in the modern Ukrainian society.

\section{Results and discussions}

According to the results of an empirical study, ethnic migrants from Kazakhstan, based on socio-demographic indicators, are presented as follows:

- by age and sex of the subjects - 48 men, 26 people $(54,2 \%)$ of which aged 19 to 25 (the period during which young people usually receive education) and 22 men (45.8\% ) from 26 to 35 years (the age of the most intense professional development and self-actualization) and 60 women, 14 people $(23.3 \%)$ aged 20 to 25 years and 46 women $(76.7 \%)$ aged 36 to 57 years old;

- according to the material status of the subjects - a high level of wealth was determined by $71 \%$ of women and $53 \%$ of men. However, poverty levels are felt by $22 \%$ of the studied both sexes;

- by the level of education - $47 \%$ of men have higher education, $20 \%$ - only basic secondary (aged from 19 to 21 years), the rest have secondary special education, which, however, allows them to maintain a sufficient level of material security. $71 \%$ of women get higher education, a significantly smaller proportion than men with medium-special education $-0.1 \%, 24 \%$ of women have only secondary education, while being below the poverty line, $80 \%$ of them aged 20 to 22 years, the rest - more than 25 ;

- by marital status - $38 \%$ of women are married, all are adults aged 25 to 35 years, 29\% are single (80\% aged under 
25 , others over 26 ), and only one woman noted that has a partner, but unmarried with him. Among men, the proportion of married people is much higher $-67 \%, 20 \%$ of men said that they are not in any relationship, the rest have admitted that they have partners, but they are not married to them.

Summing up the results of the empirical study by the E. Shostrom's self-actualization test a high enough indicators were found on the general level of actualization and their tendencies in $25 \%$ of the general sample. Thus, there are two tendencies: on the one hand, such indicators point to a good sense of life in the real, present time, they appreciate it and are able to enjoy the moods of life, and on the other hand, it can testify to a certain compensatory isolation from real problems and difficulties, it's about reasoning like «it is worth living today, to appreciate what we have now, since it is not known what we will have to meet tomorrow». At the same time, low rates indicating excessive neurotic immersion in the past and high ambitions regarding future achievements, but insufficient self-confidence to realize such ambitions is noted in less than $1 \%$ of the overall sample. In general, the sample shows a balanced level of self-actualization trends, indicating a certain realism of the perception of the environment and a realistic assessment of their own capabilities and potentials in achieving their goals. Such results confirm our previous hypotheses that voluntary migrants, while solving consciously and independently to live, study and work in our country, despite all the political, economic and cultural difficulties affecting their adaptation, have acceptable and even high potential of self-realization.

Regarding the level of socio-psychological adaptation of our studied people we can note the following: $33 \%$ of the total sample is marked with extremely high level of social and psychological adaptation, while $22 \%$ are noted to have disadaptation by general indicator of Diamond and Rogers's Methods. Practically we note that all individuals with ultra-high indicators of social and psychological adaptation, have inter- 
nality and a high level of emotional comfort. However, caution is necessary about the nature of such extremes: if this level of adaptation is less likely to be accepted by acceptance, that is, the process of dissolution in the donor culture, the loss of its own ethnic identity for the sake of the well-being and safety of living in the new society and achieving the goals set. Answers to these questions will be sought not individually for each respondent, but in a generalized way by looking for correlation links of identity loss and actual indicators of self-actualization trends and the level of social-psychological adaptation.

At the same time, we note that only $14 \%$ (according to Phinney's Scale) people from the general sample marked the dissolution of ethnic identity and the sense of belonging to their own ethnic group. An alarming one was the proportion of people who marked one or the other disorder on Beck's depression scale - above $44 \%$. One can learn about the relationship of ethnic migrants depression with specific personal characteristics and their social and psychological adaptation only in contact with the correlation analysis of the data that accurately showed the following tendencies:

- there is a close connection (at the level of reliability $\mathrm{p} \leq 0,01$ ) of the adaptation of the person with her internality, which involves the internal locus of control, the ability to take responsibility for themselves, for their own decisions and actions;

- naturally we can mark the close liaison (at the level of reliability $\mathrm{p} \leq \mathbf{0 . 0 1}$ ) of successful adaptation with individual emotional comfort, which reflects sufficient satisfaction of respondent with current affairs and life in general for now;

- it is important to pay attention to the reverse correlation ( $\mathrm{p} \leq \mathrm{0,05}$ ) of success of social and psychological adaptation of personality with depressive tendencies, while, unfortunately, we cannot speak clearly about the causal connection features like: whether the person as a result of depression is experiencing difficulties in the process of adaptation to a new 
society, or vice versa - the process of adaptation takes away all resources to overcome difficulties, as a result of which it develops emotional and cognitive tension and somatic disorders appear. Therefore, they only have to ascertain this tendency;

- we also see a similar situation with regard to ethnic identity: reverse correlation connection $(p \leq 0,05)$ with a high level of depression, especially with a cognitive-affective component $(\mathrm{p} \leq 0,01)$. Apparently ethnic migrants, whose identity is soluble in a new culture of society, simultaneously undergo depressive mood that affects the cognitive-affective sphere of personality;

- extremely interesting data failed to note on ethnic migrants internality: the older person is, the more he or she is inclined to the external control locus (reverse correlation connection level of reliability $\mathrm{p} \leq \mathbf{0 . 0 1}$ ). Certain reservations, of course, but modern dynamic living conditions have a greater impact on the formation of a young person than on the older generation, since such tendencies are confirmed in a number of other modern studies;

- we observe the expected direct correlation $(\mathrm{p} \leq \mathbf{0 . 0 1})$ of the personality internality with the self-actualization test of acceptance of aggression;

- logical, but equally interesting connection is one $(p \leq 0,05)$ of the internality of the individual with his selfacceptance on the scale of E. Shostrom's self-actualization test. And, really, it is much easier and more natural for a man who recognizes his nature, is acquainted with himself and his own abilities, competences and potencies to assume responsibility for the decisions making and committed actions than those who are not so self-confident and do not accept themselves. This can be explained also by the fact that a person who realistically and truly appreciates himself and accepts all his peculiarities and manifestations makes a more balanced decision, in particular concerning migration, counting on his own forces, realizing all the difficulties that will have to be en- 
countered in the process of adaptation period. A person who is incapable of accepting himself can either underestimate his own potential and build his hands in advance, even without trying to move forward, and to overestimate his own forces and eventually fall into a situation that he cannot handle. Under such circumstances, often the only opportunity to protect themselves from mental stress and feelings of inferiority is the transfer of responsibility to external forces and factors.

It should be noted that not only the indicated correlation links appeared to be informative, but also their absence in seemingly obvious phenomena. For example, it is worth noting that ethnic identity is in no way connected with self-actualization tendencies of the person and its socio-psychological adaptability, however, its blurriness inevitably affects the psychological state of the individual and causes mental tension. But the socio-psychological adaptation of ethnic migrants is felt tangibly, and sometimes even determines its success.

Ethnic migrants from Kazakhstan arrived to our country, consciously and independently choosing it for further residence and livelihoods, in the questionnaire, among additional information, notified that the decision on the move was significantly influenced by the events of 2013-2014, which demonstrated the potential of Ukrainians to make radical and decisive changes and rapid reform movement in the euro integration direction. Since most of the young ethnic Kazakhs who came to our sample, have Western-oriented views and world perceptions, such a step in their lives seems clear and logical. However, one should not forget about high indicators of a large part from the general sample of the level of depressive trends, indicating the impact of the general state of affairs on their psychological state, hampering the process of adaptation.

\section{Conclusions}

So, the comparative analysis of the results of the sociopsychological adaptation of ethnic migrants conducted by us 
provides grounds for arguing that the significant difference between voluntary ethnic migrants, who significantly differ in language, culture, appearance, etc. from forced migrants, even Ukrainians. Voluntary, deliberate migration hypothetically provides recipients with important benefits in the process of adapting to a new society, at least in the form of motivated by higher needs, in particular, in self-realization, and relative freedom of choice and decision-making.

The main feature of voluntary ethnic migration is its certainty and duration, as moving to our country, the recipients took an independent and informed decision about the place of residence, and, consequently, they were able to get acquainted with the culture, peculiarities of society, socio-economic and political processes in it, etc. However, this does not exclude the difficulties that inevitably arise in the process of socio-psychological adaptation in a new society for them, especially given the diversity of religions and cultures (in the case of Muslim peoples). Therefore, important tasks for the authorities and the public sector are the maintenance of socioeconomic policies aimed at adapting, integrating and socially involving this group of migrants in donor communities. Legal support and maintenance, equal access to sources of employment and additional earnings, freedom to receive higher education, implementation of security programs of other cultural groups, in order to prevent violence, are relevant for this group of our society.

However, the most important, from our point of view, is the program of comprehensive support and psychological support of ethnic migrants in the process of their socio-psychological adaptation and integration into Ukrainian society, in order to prevent the spread of negative mental states, increase in the number of suicides or suicide attempts due to inability to overcome the difficulties alone that even groups of voluntary migrants face inevitably. The transfer of ethnic voluntary migrants to the brackets of our attention and assistance, referring to their external success and security, often causes a 
latent social problem of the isolation of certain ethnic groups in the middle of society, resulting in an inductively increasing mental tension in society as a whole. After all, in fact, the ignoring of any phenomena in the society can only be conditional, in advance, feeling the approach of a social explosion.

It is reasonable to consider the following:

- the development of a network of psychological support providers not only for migrants with obvious complications of adaptation or complications that already complicate the life of society as a whole, but also provide background, basic support to all groups of migrants on request;

- providing psychological support and organization of integrational psychological groups for migratory youth (both individually and collectively) in order to reduce the level of pessimism, anomie and depression, leveling the negative impact of the difficult political and economic events that are currently in place in Ukraine;

- providing ethnic migrants with cultural objects, without which it seems impossible to support the ethnic identity of adults and its formation in children, which will be born already in our country in the event of successful social and psychological adaptation of their parents.

In a difficult financial situation, it is necessary to provide programs for improving the productivity of organizations dealing with the problems of ethnic migrants in Ukraine, namely: 1) to improve the data collection system for the needs of ethnic migrants, as well as to track the process of their further official employment; 2) provide quality and relevant programs for the retraining of ethnic migrants in accordance with the needs of the state; 3 ) ensure equal access to higher education in relevant specialties, with the further employment of a stateowned institution, to implement migrants' own knowledge, skills and abilities for the benefit of the host society. Such steps, in our opinion, will contribute to the rapid adaptation of ethnic migrants, especially those who voluntarily choose our country for residence and further professional activity. 


\section{References}

Абульханова К. А. Развитие личности в процессе жизнедеятельности. Психология форлирования и развития личности. Москва : Наука, 1981. С. 19-45.

Акопов Г. В. Ментальность как групповое сознание. Самара : ПГСГА, 2015. $76 \mathrm{c.}$

Анцыферова Л. И. Личность в трудных жизненных условиях: переосмысливание, преобразование ситуаций и психологическая защита. Психологический журнал. 1994. Т. 15. № 1. С. 3-18.

Бадмаев В. Н. Феномен национальной идентичности: социально-философский анализ: дис. ... канд. филос. наук. Волгоград, 2005. 292 с.

Барышева Ю. С. Социокультурная адаптация мигрантов в условиях современного мегаполиса: на примере Москвы: автореф. дис. ... канд. культурологии: спец. 24.00.01 «Теория и история культуры». Москва, 2007. 22 с.

Березин Ф. Б. Психическая и психофизиологическая адаптация человека. Ленинград : Наука, 1988. 270 с.

Берри Дж. Кросс-культурная психология: исследования и применение. Харьков : Гуманитарный центр, 2007. 558 с.

Блинова О. Є. Трудова міграція населення України у соціально-психологічному вимірі: монографія. Херсон : РІПО, 2011. 486 с.

Гриценко В. В. Теоретические основы исследования социально-психологической адаптации личности / группы в новой социо- и этнокультурной среде. Проблемы социальной психологии личности: межвуз. сб. науч. тр. Саратов : Изд-во СГУ, 2005. Вып. 2. С. 9-28.

Данилюк І. В. Психологічні технології самодетермінації розвитку особистості: монографія. Київ : Інститут психології ім. Г. С. Костюка НАПНУ, 2018. С. 25-33.

Довгалева И. В. Социальные практики адаптации: идентификационный дискурс : дис. ... канд. философ. н.: 09.00.11. Тверь, 2010. 162 с.

Життєві домагання особистості: монографія / За ред Т. М. Титаренко. Київ : Педагогічна думка, 2007. 455 с.

Кириллова А. И. Взаимодействие культур: интеграция, ассимиляция и воспитательная роль общества. NB: Проблелы общества и политики. 2013. № 1. С. 53-152.

Найдьонова Л. А. Рефлексивна психологія територіальних спільнот. Київ : Міленіум, 2012. 275 с.

Налчаджян А. А. Социально-психическая адаптация личности (формы, механизмы и стратегии). Ереван : Изд-во АН АрмССР, 1988. 263 с.

Овсяник О. А. Социально-психологические особенности адаптации личности [Электронный ресурс]. Совреленные исследования социальных проблем. Красноярск, 2012. № 1 (09). Режим доступа : http:// sisp.nkras.ru/issues/2012/1/ovsyanik.pdf. 
Панина Н. В. Факторы национальной идентичности, толерантности, ксенофобии и антисемитизма в современной Украине. Социология: теория, методы, маркетинг. 2005. № 4. С.26-45.

Смотрицкий А. В. Трансформация социальной идентичности добровольных мигрантов в условиях мегаполиса. Проблели політичної ncuхологї̈: зб. наук. пр. Київ : Міленіум, 2015. Вип. 2 (16). С. 189-198.

Султанова Н. Д. Временной и содержательный аспекты в развитии личности вынужденных мигрантов. Теоретические проблелы этнической и кросскультурной психологии: лмтериалы Четвертой Международной научной конференции. В 2 т. / Отв. ред. В.В. Гриценко. Смоленск : СГУ, 2014. Т. 2. С. 136-140.

Berry J. W. (2006). Immigrant youth in cultural transition: Acculturation, identity and adaptation across national contexts. Journal of CrossCultural Psychology. London : Lawrence Erlbaum. P. 336.

Mead G. H. (1913). The social self. Journal of Philosophy, Psychology and Scientific Methods, 10, 374-380.

\section{References}

Abul'hanova, K. A. (1981). Razvitie lichnosti v processe zhiznedejatel'nosti [The development of the personality in the process of vital activity]. Psihologija formirovanija i razvitija lichnosti - The psychology of personality's formation and development. Moskva : Nauka (pp. 19-45) [in Russian].

Akopov, G. V. (2015). Mental'nost' kak gruppovoe soznanie [Mentality as a group consciousness ]. Samara : PGSGA [in Russian].

Ancyferova, L. I. (1994). Lichnost' v trudnyh zhiznennyh uslovijah: pereosmyslivanie, preobrazovanie situacij i psihologicheskaja zashchita [Personality in difficult life conditions: rethinking, transforming situations and psychological defense]. Psihologicheskij zhurnal Psychological journal, 15, 1, 3-18 [in Russian].

Badmaev, V. N. (2005). Fenomen nacional'noj identichnosti: social'no-filosofskij analiz [The phenomenon of national identity: social and philosophical analysis]. Candidate's thesis. Volgograd [in Russian].

Barysheva, Ju. S. (2007). Sociokul'turnaja adaptacija migrantov v uslovijah sovremennogo megapolisa: na primere Moskvy [Social and cultural adaptation of migrants in the conditions of the modern metropolis: the example of Moscow]. Extended abstract of candidate's thesis. Moskva [in Russian].

Berezin, F. B. (1988). Psihicheskaja i psihofiziologicheskaja adaptacija cheloveka [Mental and psychophysiological human adaptation]. Leningrad : Nauka [in Russian].

Barri, J. (2007). Kross-kul'turnaja psihologija: issledovanija i primenenie [Cross-cultural psychology: research and application]. Har'kov : Gumanitarnyj centr [in Russian]. 
Blynova, O. Ye.(2011). Trudova mihratsiia naselennia Ukrainy u sotsialnopsykholohichnomu vymiri [Labor migration of the population of Ukraine in the socio-psychological dimension]. Kherson : RIPO [in Ukrainian].

Gricenko, V. V. (2005). Teoreticheskie osnovy issledovanija social'no-psihologicheskoj adaptacii lichnosti / gruppy v novoj socio- i jetnokul'turnoj srede [Theoretical foundations of the study of the sociopsychological adaptation of an individual / group in a new socio- and ethnocultural environment]. Problemy social'noj psihologii lichnosti - Problems on a social psychology of a personality, 2, 9-28. Saratov : Izd-vo SGU [in Russian].

Danyliuk, I. V. (2018). Psykholohichni tekhnolohii samodeterminatsii rozvytku osobystosti [Psychological technologies of self-determination of personality's development]. Kyiv : Instytut psykholohii im. H. S. Kostiuka NAPN Ukrainy [in Ukrainian].

Dovgaleva, I. V. (2010). Social'nye praktiki adaptacii: identifikacionnyj diskurs [Social Adaptation Practices: Identification Discourse]. Candidate's thesis. Tver' [in Russian].

Tytarenko, T. M. (Eds.). (2007). Zhyttievi domahannia osobystosti [Life claims of personality]. Kyiv : Pedahohichna dumka [in Ukrainian].

Kirillova, A. I. (2013). Vzaimodejstvie kul'tur: integracija, assimiljacija i vospitatel'naja rol' obshchestva [The interaction of cultures: integration, assimilation and the educational role of society]. NB: Problemy obshchestva i politiki - Problems of Society and Politics, 1, 53-152 [in Russian].

Naidionova, L. A. (2011). Refleksyvna psykholohiia terytorialnykh spilnot [Reflexive psychology of territorial communities]. Kyiv : Millenium [in Ukrainian].

Nalchadzhjan, A. A (1988). Social'no-psihicheskaja adaptacija lichnosti (formy, mehanizmy $i$ strategii) [Socio-psychological adaptation of the personality (forms, mechanisms and strategies)]. Erevan : Izd-vo AN ArmSSR [in Russian].

Ovsjanik, O. A. (2012). Social'no-psihologicheskie osobennosti adaptacii lichnosti [Socio-psychological characteristics of personal adaptation]. Sovremennye issledovanija social'nyh problem - Contemporary studies of social problems, 1 (09). Krasnojarsk. Retrieved from http://sisp.nkras.ru/issues/2012/1/ovsyanik.pdf [in Russian].

Panina, N. V. (2005). Faktory nacional'noj identichnosti, tolerantnosti, ksenofobii i antisemitizma v sovremennoj Ukraine [Factors of national identity, tolerance, xenophobia and anti-semitism in modern Ukraine]. Sociologija: teorija, metody, marketing - Sociology: theory, methods, marketing, 4, 26-45 [in Russian].

Smotrytskyi, A. V. (2015). Transformacija social'noj identichnosti dobrovol'nyh migrantov $\mathrm{v}$ uslovijah megapolisa [Transformation of the 
social identity of voluntary migrants in a megacity]. Problemy politychnoi psykholohii - Problems of Political Psychology, 2 (16), 189198. Kyiv : Millenium [in Ukrainian].

Sultanova, N. D. (2014). Vremennoj i soderzhatel'nyj aspekty v razvitii lichnosti vynuzhdennyh migrantov [Time and content aspects in the development of the personality of forced migrants]. V. V. Gricenko (Eds.). Teoreticheskie problemy jetnicheskoj i krosskul'turnoj psihologii - Theoretical problems of ethnic and cross-cultural psychology: Proceedings of the fourth International Scientific Conference, 2 , 136-140. Smolensk : SGU [in Russian].

Berry J. W. (2006). Immigrant youth in cultural transition: Acculturation, identity and adaptation across national contexts. Journal of CrossCultural Psychology. London : Lawrence Erlbaum.

Mead G. H. (1913). The social self. Journal of Philosophy, Psychology and Scientific Methods, 10, 374-380.

\section{Ващенко Ірина, Ріттель Юлія. Особливості соціально-психологічної адаптації особистості в ситуації етнічної міграції}

\section{АНОТАЦІЯ}

Статтю присвячено проблемі особливостей соціально-психологічної адаптації особистості в ситуації етнічної міграції. Увагу акцентовано на категорії добровільних етнічних мігрантів, котрі перебувають у процесі соціально-психологічної адаптації до умов українського мегаполіса. Проаналізовано зовнішні та внутрішні чинники соціальнопсихологічної адаптації, вплив віку етнічних мігрантів із Казахстану на успішність процесу адаптації. Емпірично виокремлено трудноші, з якими вони стикаються під час соціально-психологічної адаптації до нового соціуму, та параметри, що впливають на успішність взаємодії різних культур у суспільстві. За результатами кореляційного аналізу отриманих даних з'ясовано, що добровільні етнічні мігранти з Казахстану віком від 18 до 35 років, вирішуючи свідомо і самостійно проживати, навчатися та працювати в Україні, володіють прийнятними й навіть високими потенціями самореалізації. Доведено, що їх етнічна ідентичність жодним чином не пов'язана із самоактуалізаційними тенденціями особистості та ії адаптованістю. Однак етнічна ідентичність відчутно позначається на соціально-психологічній адаптації етнічних мігрантів, а іноді навіть визначає ї̈ успішність. Запропоновано варіант програми усебічної підтримки та психологічного супроводу етнічних мігрантів у процесі їх соціально-психологічної адаптації. 
Ключові слова: добровільна етнічна міграція, адаптація особистості, соціально-психологічна адаптація, вираженість етнічної приналежності, самоактуалізація, депресія, український мегаполіс, психологічний супровід, етнічна ідентичність.

Ващенко Ирина, Риттель Юлия. Особенности социально-психологической адаптации личности в ситуации этнической миграции

\section{АННОТАЦИЯ}

Статья посвящена проблеме особенностей социально-психологической адаптации личности в ситуации этнической миграции. Внимание акцентировано на категории добровольных этнических мигрантов, находящихся в процессе социально-психологической адаптации к условиям украинского мегаполиса. Проанализированы внешние и внутренние факторы социально-психологической адаптации, влияние возраста этнических мигрантов из Казахстана на успешность процесса адаптации. Эмпирически выделены трудности, с которыми они сталкиваются во время социально-психологической адаптации к новому социуму, и параметры, которые влияют на успешность взаимодействия различных культур в обществе. По результатам корреляционного анализа полученных данных выяснено, что добровольные этнические мигранты из Казахстана в возрасте от 18 до 35 лет, решая сознательно и самостоятельно проживать, учиться и работать в Украине, обладают приемлемыми и даже высокими потенциями самореализации. Доказано, что их этническая идентичность никоим образом не связана с самоактуализационными тенденциями личности и ее адаптированностью. Однако этническая идентичность ощутимо сказывается на социально-психологической адаптации этнических мигрантов, а иногда даже определяет ее успешность. Предложен вариант программы всесторонней поддержки и психологического сопровождения этнических мигрантов в прочессе их социально-психологической адаптации.

Ключевые слова: добровольная этническая миграция, адаптация личности, социально-психологчческая адаптация, выраженность этнической принадлежности, самоактуализация, депрессия, украинский мегаполис, психологическое сопровождение, этническая идентичHocmb. 